DOI 10.14746/ssp.2016.1.5

Krzysztof KoźBiAŁ

Uniwersytet Jagielloński

\title{
Współpraca transgraniczna na poziomie lokalnym. Opinie mieszkańców gmin powiatu kłodzkiego na temat kooperacji z partnerem czeskim. Analiza przypadku
}

Streszczenie: Badania, prowadzone metodą wywiadów pogłębionych, objęły dwie gminy pow. kłodzkiego: Nową Rudę (gmina wiejska) i Szczytną. Dotyczyły postrzegania współpracy transgranicznej. Ma ona miejsce na ziemi kłodzkiej od początku lat 90. XX stulecia, choć zwraca uwagę fakt, iż po wejściu Polski i Czech do UE nastąpiło jej zauważalne pogłębienie.

Badania wykazały, iż kooperacja ponadgraniczna nie jest tematem szeroko znanym wśród mieszkańców tych gmin. Mimo to formułują oni pozytywne oceny tego rodzaju działań uznając, iż przyczyniają się do lepszego wzajemnego poznania i częstych kontaktów bezpośrednich między Polakami i Czechami. W istotnym stopniu kooperacja ta ma wpływ na postrzeganie południowych sąsiadów, które należy ocenić jako pozytywne. Wielu rozmówców uznało Republikę Czeską wręcz za wzór gospodarności. Ocena ta była jednak powierzchowna, nie poparta konkretnymi dowodami.

Współpraca transgraniczna na ziemi kłodzkiej dotyczy głównie takich sfer jak turystyka i kultura, w większości przypadków jest koordynowana przez urzędy gmin i podległe im jednostki. Zaangażowanie organizacji pozarządowych w te procesy jest, w ocenie pytanych, mało zauważalne. Dla jej wzmocnienia niezbędne byłoby ulepszenie sieci komunikacyjnej, w szczególności połączeń kolejowych.

Słowa kluczowe: ziemia kłodzka, współpraca transgraniczna, Polska, Czechy

$\mathbf{I}$ ntegracja europejska bez wątpienia sprzyja współpracy międzynarodowej, także na poziomie lokalnym. Przykładem tego zjawiska jest powiat kłodzki, odrodzony w wyniku reformy samorządowej końca lat 90. minionego wieku. Na odcinku aż 192 km graniczy on z Republiką Czeską. Nic zatem dziwnego, iż jednostki samorządu terytorialnego tego zakątka Polski prowadzą ożywioną kooperację transgraniczną.

Badania stanowiące podstawę artykułu były prowadzone w latach 2012-2014 przez zespół naukowców Instytutu Europeistyki Uniwersytetu Jagiellońskiego w ramach grantu badawczego NCN ${ }^{1}$. Na ziemi kłodz-

${ }^{1}$ Współpraca transgraniczna na poziomie lokalnym. Projekt został sfinansowany ze środków Narodowego Centrum Nauki przyznanych na podstawie decyzji numer DEC-2011/03/B/HS6/01163. 
kiej w gminach Szczytna i Nowa Ruda (gmina wiejska) przeprowadzono w sumie ok. 80 wywiadów pogłębionych. Zastosowanie tej metody badawczej pozwoliło na uzyskanie spostrzeżeń odnoszących się m.in. do tego jak mieszkańcy pogranicza postrzegają współpracę transgraniczną z Republiką Czeską. Z czym kojarzą określenie „współpraca transgraniczna"? Jak ją oceniają? Czy widzą jakieś jej mankamenty? Wreszcie jak postrzegana jest Republika Czeska jako państwo i Czesi jako osoby, z którymi kooperacja ma miejsce?

\section{Charakterystyka powiatu kłodzkiego}

Utworzony w ramach reformy samorządowej, która weszła w życie 1 stycznia 1999 roku powiat kłodzki jest największym powiatem woj. dolnośląskiego. Zajmuje powierzchnię $1642 \mathrm{~km}^{2}$, zamieszkuje go ponad 164,6 tys. mieszkańców (Powierzchnia, 2014, s. 17-18). Należy zaakcentować rozległość tejże jednostki samorządowej, która pod tym względem znajduje się na 25 miejscu w kraju, ale równocześnie jej wysoką liczbę mieszkańców (13 miejsce w Polsce). Powinno to stanowić podstawę do solidnego rozwoju, także gospodarczego, co jednak nie ma miejsca.

$\mathrm{W}$ takim kształcie terytorialnym powiat ten zaistniał po raz pierwszy. Wcześniej funkcjonowały bowiem na tym obszarze dwie, a nawet trzy jednostki samorządu lokalnego. W latach 1855-1932 oraz 1954-1975 istniał powiat noworudzki. Z kolei nieprzerwanie od 1815 do 1975 r. funkcjonowały powiaty bystrzycki i kłodzki (zob. szerzej: Trzebiński, 1952). Dopiero reforma administracyjna przeprowadzona w połowie lat 70 . XX stulecia zniosła szczebel powiatowy, a wspomniany obszar znalazł się w woj. wałbrzyskim.

W skład obecnej rozległej jednostki wchodzi 14 gmin: 5 miejskich (Duszniki Zdrój, Kłodzko, Kudowa Zdrój, Nowa Ruda i Polanica Zdrój), 6 gmin miejsko-wiejskich (Bystrzyca Kłodzka, Lądek Zdrój, Międzylesie, Radków, Stronie Śląskie i Szczytna) oraz 3 gminy o charakterze wiejskim (Kłodzko, Lewin Kłodzki, Nowa Ruda). Aż w 11 przypadkach mamy zatem do czynienia $\mathrm{z}$ różnej wielkości miastami.

Pograniczność charakteryzowała ów obszar od najdawniejszych czasów. Po zakończeniu I wojny światowej ówczesna granica (tożsama z obecna) rozdzielała Republikę Weimarską, później III Rzeszę, od Republiki Czechosłowackiej. Także wówczas miały miejsce kontakty ponad granica, choć o charakterze ograniczonym, wynikające m.in. z faktu, iż 
po stronie niemieckiej - w tzw. Czeskim Kątku wokół Kudowy Zdroju - zamieszkiwała kilkutysięczna grupa ludności czeskiej. Używanie języka czeskiego utrzymywało się aż przynajmniej do lat 80. XX stulecia (zob. szerzej: Goliński, 1994; Siatkowski, 1990). Ludność z Czechosłowacji często przekraczała granice, aby udać się do znanego na Dolnym Śląsku miejsca pielgrzymkowego, jakim były i są Wambierzyce.

Po praktycznie prawie całkowitej wymianie ludności, jaka miała miejsce na ziemi kłodzkiej po zakończeniu II wojny światowej, w wyniku której obszar ten stopniowo opuściła ludność niemiecka i czeska, a ze wschodu została tamże przesiedlona ludność polska, obszar powiatów kłodzkiego i bystryckiego pozostał „pograniczny”. W okresie istnienia Polskiej Rzeczpospolitej Ludowej trudno dostrzec ożywioną kooperację na styku dwóch państw, które raczej teoretycznie niż praktycznie były państwami przyjaznymi. Faktem sąjednak kontakty ludności, wyrażające się dojazdami do pracy po stronie czechosłowackiej, w której brali udział mieszkańcy przygranicznych gmin obu powiatów. Tym samym zmiany możliwe po wejściu Polski i Czech do strefy Schengen w 2007 r. z praktycznego punktu widzenia nie były dla mieszkańców Kłodzkiego aż takim novum jak mogłoby się wydawać. Tego rodzaju doświadczenia były tam już znane znacznie wcześniej.

\section{Stan współpracy transgranicznej z Republiką Czeską na pograniczu ziemi kłodzkiej}

Termin współpraca transgraniczna nie jest definiowany w sposób jednoznaczny. Jej cechą muszą być bez wątpienia działania prowadzone po obu stronach granicy, przy czym bezpośrednie sąsiedztwo jednostek współpracujących nie wydaje się konieczne. Tego rodzaju współpraca powinna dotyczyć różnych sfer: społecznej, gospodarczej, kulturalnej itp.

Jak zauważa E. Szadkowska jest to rodzaj kooperacji o charakterze sąsiedzkim, między regionami, władzami samorządowymi i innymi podmiotami. Co istotne, powinna ona wzmacniać kontakty sąsiedzkie między wspólnotami na poziomie lokalnym, tworzyć sieci powiązań między nimi i przyczyniać się do znoszenia barier i wzrostu zaufania między społecznościami przygranicznymi (Szadkowska, 2010, s. 14-16). Kooperacja transgraniczna prowadzona jest, jak wspomniano, w wielu obszarach. Najczęściej odnosi się do rozwiązań infrastrukturalnych, wymiany kulturalnej i oświatowej, turystyki, ochrony środowiska naturalnego, informa- 
cji i promocji. Często przybiera formę zinstytucjonalizowaną w postaci euroregionów. Te formy zakładają współpracę długofalową (Szadkowska, 2010, s. 16-17).

Nie sposób oprzeć się wrażeniu, iż proces integracji europejskiej, którym obszary pogranicza ziemi kłodzkiej zostały objęte de facto w latach 90. minionego wieku, przyczynił się do intensyfikacji współpracy po obu stronach granicy. Zjawisko to dostrzegali także badani. Wsparcie ze środków unijnych przeznaczone na realizację licznych projektów przyczyniło się zatem do podniesienia współpracy na obszarach transgranicznych na wyższy poziom. Było to zauważalne zarówno w okresie 2007-2013, jak i obecnie.

Na pograniczach Polski proces kooperacji z jednostkami samorządu terytorialnego znajdującymi się po drugiej stronie granicy stał się zauważalny po upadku komunizmu. Wcześniej miejsca styku państw przedstawiane w okresie PRL-u jako ,granice przyjaźni” w praktyce stanowiły nierzadko barierę nie do przebycia. W konsekwencji współpraca samorządów była iluzoryczna. Często sprowadzała się do partnerstwa miast, ale i w tym przypadku o zauważalnym przełomie można mówić dopiero od lat 90. minionego wieku.

Powiat kłodzki można uznać pod tym względem za beneficjenta procesu związanego z upadkiem żelaznej kurtyny. Otwarcie na współpracę na poziomie lokalnym stopniowo przyczyniło się do lepszego poznania partnerów po obu stronach granicy, a także realizacji wielu projektów stawiających przed sobą taki właśnie cel. Był to proces stopniowy, dokonujący się w zasadzie także współcześnie.

Obecnie można wskazać dwie formy transgranicznej kooperacji na badanym obszarze. Po pierwsze, poszczególne miasta i gminy, w momencie powstania także powiat kłodzki, nawiązywały współpracę bilateralną. Partnerem czeskim powiatu jest obecnie Stowarzyszenie Miast i Gmin Orlicko. Współpraca transgraniczna zajmuje ważne miejsce w aktualnej strategii rozwoju powiatu na lata 2008-2015. Do mocnych stron kooperacji zalicza się położenie powiatu, liczne przykłady współpracy z czeskim partnerem, praktyczny brak bariery językowej, modernizację dróg przeprowadzoną w związku z pełnym otwarciem granicy, wreszcie członkostwo Polski i Czech w strefie Schengen. Do słabych stron należą: brak publicznej komunikacji o charakterze transgranicznym, niepełne wykorzystanie możliwości kooperacji czy też brak nauczania języka sąsiada w szkołach po obu stronach granicy. Wśród zadań zrealizowanych dostrzega się głownie dużą liczbę inicjatyw 
w dziedzinie turystyki², komunikacji i sportu. Władze powiatu oceniają, iż obecnie współpraca ta wchodzi w drugi etap, niezwykle istotną w nim rolę mają odegrać projekty o charakterze komunikacyjnym, ponadregionalnym, np. realizacja budowy drogi S5 mającej docelowo łączyć Wrocław z Brnem i Wiedniem (Strategia, 2008, s. 92-94).

Drugą, niezwykle zauważalną, formą współpracy transgranicznej na obszarze pogranicza kłodzkiego są kontakty bilateralne między poszczególnymi miastami i gminami. Ten rodzaj współpracy, co dowiodły przeprowadzone badania, jest bardziej dostrzegalny przez mieszkańców gmin, co nie dziwi wziąwszy pod uwagę fakt ich wyższego poziomu wiedzy na temat inicjatyw podejmowanych na obszarze podstawowych jednostek samorządu. Wszystkie gminy wchodzące w skład powiatu posiadają partnerów także po stronie czeskiej, niektóre z nich po kilka miast (gmin) partnerskich.

W gminach, w których prowadzono badania współpraca transgraniczna z Czechami także ma charakter zinstytucjonalizowany. W grudniu 1992 r. gmina wiejska Nowa Ruda (wraz z miastem) podpisała porozumienie o współpracy z miastem Broumov. Natomiast gmina Szczytna od 2000 r. współpracuje z gminą Velké Poříčí. W obu przypadkach są to jedyni partnerzy czescy.

Poważne miejsce w kooperacji transgranicznej zajmuje euroregion obejmujący swym zasięgiem ziemię kłodzką i będący jednym z pięciu na styku Polski i Czech. Zainicjowanie jego utworzenia związane jest z działalnością opozycji demokratycznej i inicjatywami, które ujrzały światło dzienne na początku lat 90 . XX stulecia. Nie sposób nie wspomnieć w tym miejscu o publikacji Ziemia Kłodzka - Od Kladského pomezi - Glatzer Bergland, która z czasem przybrała formę miesięcznika wydawanego w trzech językach, i organizowaniu od 1990 r. PolskoCzeskich Dni Kultury Chrześcijańskiej. W maju 1990 r. w Nachodzie doszło do spotkania przygranicznych społeczności, co uznawane jest za początek stałej kooperacji w tym rejonie. Od 1994 r. gminy pogranicza kłodzkiego współdziałały w ramach Stałego Regionu Współpracy Polsko-Czeskiej. Od tego też momentu rozważano możliwość utworzenia euroregionu. Euroregion Glacensis ${ }^{3}$ (nazwa odnosiła się do łacińskiego

${ }^{2} \mathrm{Na}$ mocy porozumienia z partnerem czeskim powiat kłodzki może na przykład bezpłatnie brać udział w targach turystycznych odbywających się w Brnie (,Go” i „Regiontour”), Pardubicach („Regiontour”) i Pradze (,Holiday World”).

3 Obecnie członkami Euroregionu Glacensis są wszystkie gminy powiatu kłodzkiego. 
określenia obszaru pokrywającego się w dużym stopniu ze współczesną ziemią kłodzką) powstał 5 grudnia 1996 r. po podpisaniu umowy między partnerami polskimi i czeskimi. Jego siedzibą po stronie czeskiej jest miasto Rychnov nad Kněžnou, po polskiej Kłodzko. Obejmuje obszar ponad 5 tys. $\mathrm{km}^{2}$ i jest zamieszkiwany przez ok. $1 \mathrm{mln}$ ludności (Euroregiony, 2007, s. 89-90; 15 lat, 2015, s. 13-15).

W działalności Euroregionu Glacensis istotne znaczenie miały środki pozyskiwane z czterech programów pomocowych UE: Phare CREDO, Phare CBC, inicjatywy INTERREG III A oraz Programu Operacyjnego Współpracy Transgranicznej Republika Czeska - Rzeczpospolita Polska 2007-2013. Do sierpnia 2011 r. obszar euroregionu otrzymał w sumie wsparcie na sumę ponad 88,3 mln euro (15 lat, 2015, s. 13-15).

W latach 2007-2013 na pograniczu obu państw realizowano program operacyjny dotyczący współpracy transgranicznej, zatwierdzony przez Komisję Europejską w grudniu 2007 r., o budżecie wynoszącym ponad $258 \mathrm{mln}$ euro (z czego wkład Unii to prawie $219,5 \mathrm{mln}$ ). Jego priorytety wynikały z najistotniejszych problemów dostrzegalnych po obu stronach granicy, do których zaliczono przede wszystkim problemy wynikające $\mathrm{z}$ restrukturyzacji przemysłu i rolnictwa, i w konsekwencji spadek liczby zatrudnionych. Za główny cel działań uznano podniesienie atrakcyjności regionów przygranicznych. Do wspomnianych priorytetów programu należały:

- poprawa warunków rozwoju przedsiębiorczości i turystyki (w sumie $36 \%$ całości środków programu);

- wzmacnianie dostępności komunikacyjnej, ochronę środowiska i profilaktykę zagrożeń (32\% środków);

- wspieranie współpracy społeczności lokalnych (26\%);

- pomoc techniczna (6\%) (Program, 2008).

Uwagi respondentów badań odnosiły się właśnie do tego okresu, bowiem wywiady zostały przeprowadzone w latach 2012-2014. Uzasadnione wydaje się sformułowanie opinii, iż wymienione priorytety są dostrzegalne przez mieszkańców pow. kłodzkiego, gdyż o tego typu przedsięwzięciach wspominano najczęściej.

Współpraca samorządów w pasie przygranicznym na południowej granicy Polski oceniana jest zresztą szczególnie wysoko, jako ta, która przyczyniła się do zauważalnego rozwoju po obu stronach granicy. Wśród dużej liczby realizowanych projektów dominują związane z turystyka, co trudno uznać za zaskakujące (Skorupska, 2015, s. 34).

W 2014 r. woj. dolnośląskie zgłosiło akces do Europejskiego Ugrupowania Współpracy Terytorialnej (EUWT), które jest nową formą 
współpracy na obszarach pogranicznych przynajmniej dwóch państw członkowskich UE4. Nowe EUWT stawia sobie za cel bardziej efektywne wykorzystanie funduszy dotyczących projektów transgranicznych. Niniejszy artykuł nie odnosi się do tej formy kooperacji, ponieważ znajduje się ona zaledwie w początkowej fazie istnienia.

Warto zaznaczyć, iż aktywność jednostek samorządu terytorialnego dotycząca pozyskiwania unijnych funduszy była na opisywanym obszarze zróżnicowana. W okresie 2008-2011, kiedy to analizą objęto 183 wnioski złożone przez polskich beneficjentów, starania o dofinansowanie podjęło 82\% członków Euroregionu Glacensis po stronie polskiej. Gmina wiejska Nowa Ruda nie otrzymała dofinansowania na żaden projekt, z kolei gmina Szczytna uzyskała wsparcie na 4 projekty ${ }^{5}$ (Żochowska, 2011, s. 144-147). Na tym poziomie widoczna jest większa aktywność gminy Szczytna, choć wyniki badań nie potwierdzają tego wniosku.

A. Skorupska, analizując kooperację na pograniczu Polski i Czech, zwraca uwagę na dostrzegalne różnice, które utrudniają współdziałanie. Zalicza do nich m.in.: 1) różnice w podziale administracyjnym (po stronie polskiej z reguły duże gminy, miejskie, jak i wiejskie, po czeskiej małe gminy, tamtejsze urzędy zatrudniają po kilka osób); 2) brak liderów przyczyniających się do aranżowania współpracy; 3) różnice w podejściu do kooperacji i poziom wsparcia dla nich ze strony władz lokalnych (Skorupska, 2014, s. 5-6). Jednak na przykładzie ziemi kłodzkiej trudno byłoby potwierdzić, iż faktycznie czynniki te znajdują odzwierciedlenie.

Wśród rekomendacji dla dalszej współpracy ta sama autorka wskazuje m.in. na konieczność usprawnienia infrastruktury kolejowej i drogowej, rozważenie możliwości nauczania j. czeskiego (odpowiednio polskiego w Czechach) w szkołach na pograniczu, wzrost zaangażowania we wzmocnienie współpracy ze strony władz regionalnych i rządowych, wreszcie nasilenie działań promocyjnych, których celem powinno stać się de facto rozpowszechnienie informacji o efektach współpracy wśród społeczności lokalnych (Skorupska, 2014, s. 6-7).

W ocenie ekspertów polskich i czeskich wciąż dostrzegalne są ograniczenia przyczyniające się do niepełnego wykorzystania możliwości współpracy transgranicznej. Co gorsza, miejscami ciagle widoczna jest

${ }^{4}$ Członkami EUWT Novum (pierwotnie używano nazwy Nowe Sudety) są: woj. dolnośląskie oraz czeskie Kraje: Liberecki, Kralovohradecki, Pardubicki i Ołomuniecki, a także polskie i czeskie części Euroregionów Nysa i Glacensis.

${ }_{5}$ Największa aktywnością wykazała się gmina Bystrzyca Kłodzka, składając 16 wniosków. 
mentalna granica związana z uprzedzeniami wynikającymi ze złożonej historii wzajemnych stosunków. Nowym zjawiskiem są migracje zarobkowe, przede wszystkim Polaków do Czech. Wśród rekomendacji dla obu stron wymienia się m.in.: zwiększenie porozumień tzw. miast partnerskich, wymianę informacji i ofert dotyczących rynku pracy, wreszcie ciagłe zwracanie uwagi na rozwój turystyki na pograniczu oraz nacisk na pogłębianie kontaktów międzyludzkich (Dostál, Kałan, 2014).

Są to spostrzeżenia, które w dużym stopniu korespondują z rezultatami badań prowadzonych $\mathrm{w}$ ramach grantu NCN. Mimo dostrzegalnych pozytywnych zmian w tym zakresie ziemia kłodzka ciagle wymaga przede wszystkim poprawy infrastruktury komunikacyjnej łączącej z Czechami. Bolączką jest głównie brak połączenia kolejowego na odcinku Kłodzko-Náchod. Języka czeskiego nie naucza się w szkołach na terenie powiatu, choć wydawałoby się to wręcz pożądane ${ }^{6}$. Znajomość tego języka byłaby handicapem dla osób podejmujących zatrudnienie po drugiej stronie granicy, co jest faktycznie zjawiskiem coraz częstszym. Bezspornie istotna jest kwestia promocji efektów współpracy transgranicznej. Z badań jednoznacznie wynika, że wiedza respondentów na ten temat jest najczęściej stosunkowo niewielka (lub nie ma jej wcale). Część projektów i dokonań nie jest przez te osoby łączona ze współpracą ponad granicami. Zjawisko wyjazdów (lub codziennych dojazdów) do pracy jest zauważalne przez prawie wszystkich pytanych, jest ono bez wattpienia nowe i należy być może spodziewać się pogłębienia tego trendu.

\section{Współpraca transgraniczna z Czechami w opinii respondentów}

Badania w gminach Szczytna i Nowa Ruda prowadzono metodą wywiadu pogłębionego. Pytania odnosiły się do różnych sfer związanych zarówno z polskim uczestnictwem w Unii Europejskiej, jak i innymi zagadnieniami związanymi z funkcjonowaniem społeczności lokalnych. Część z nich dotyczyła także współpracy transgranicznej z Czechami.

Tematyka kooperacji z partnerami czeskimi na ziemi kłodzkiej była podejmowana przez rozmówców raczej chętnie. Nie napotkano kłopotów w rozmowach na ten temat, nie wzbudzał on negatywnych emocji. Nie oznacza to, iż zagadnienie to było bardzo dobrze znane. Zasadniczo

${ }^{6}$ Faktem jest, iż respondenci nie zwracali na to bezpośredniej uwagi (poza pojedynczymi przypadkami), uznając, iż nie stanowi to jakiejkolwiek bariery w porozumiewaniu się. 
poziom wiedzy na ten temat odzwierciedla bezpośrednie zetknięcie się z konkretnymi projektami, mówiąc wprost skorzystanie z efektów tejże współpracy. Osoby, które albo brały udział w przeprowadzeniu określonych projektów (biernie bądź czynnie) legitymizowały się z reguły stosunkowo wysokim stopniem wiedzy dotyczących tych zagadnień.

Rozmawiający nierzadko wracali pamięcią do początku lat 90. XX wieku, kiedy to dochodziło do inauguracji bliższych kontaktów z partnerami z drugiej strony granicy. W ocenie niektórych w tym okresie współpraca ze stroną czeską miała być bardziej rozwinięta niż obecnie. Jako dowód podawano często cyklicznie odbywające się imprezy na pograniczu, w szczególności Polsko-Czeskie Dni Kultury Chrześcijańskiej ${ }^{7}$ $\left(\mathrm{NR} / \mathrm{B} / 01^{8}, \mathrm{NR} / \mathrm{B} / 06, \mathrm{NR} / \mathrm{L} / 01, \mathrm{NR} / \mathrm{SO} / 04, \mathrm{NR} / \mathrm{L} / 03, \mathrm{NR} / \mathrm{W} / 02\right)$. W tym też kontekście zwracano uwagę, iż istotne miejsce w zainicjowaniu wspólnych działań zajmuje osoba, którą można określić mianem „lokalnego lidera", będącego motorem napędowych przedsięwzięć. Za taką osobę uznaje się Juliana Golaka9 . Zapewne z racji miejsca pochodzenia jest on postacią o wiele bardziej rozpoznawalną w gminie Nowa Ruda.

Nie wszyscy zgadzali się jednak ze stwierdzeniem, iż to w latach 90. wspomniana kooperacja była bardziej rozwinięta (SZ/SZ/07). Rozmówcy wskazywali, iż jej prawdziwym katalizatorem było mimo wszystko wstąpienie obu państw do Unii Europejskiej w 2004 r. (NR/NR/01). Niektórzy twierdzili wręcz, iż „UE o tyle przyspiesza tę współpracę, że z tego wynikają korzyści finansowe" (NR/P/02), względnie ,jak się pojawiły pieniądze no to wtedy, wiadomo, człowiek jest taki, że musi mieć korzyść" (NR/SO/04). Wynikałoby zatem z tego, iż czynnik finansowy odgrywa we współpracy istotną rolę od momentu członkostwa w UE, gdyż - jak wspomniano - od tego momentu na projekty realizowane na pograniczu przeznaczono o wiele większe środki niż wcześniej.

Dla części rozmówców momentem nie bez znaczenia dla kontaktów przygranicznych było wejście Polski i Czech do strefy Schengen (gru-

${ }^{7}$ Impreza odbywa się do 1990 r. Jednym z jej celów jest promowanie współpracy przygranicznej obu państw.

${ }^{8}$ Oznaczenia te odnoszą się do poszczególnych wywiadów. NR oznacza gminę Nowa Ruda, SZ - gminę Szczytna. Dalsze oznaczenia to miejscowości i numery wywiadów.

9 Julian Golak urodził się w Nowej Rudzie w 1957 r. Działacz opozycyjny, aresztowany podczas stanu wojennego. W 1989 r. współtwórca Komitetu Obywatelskiego i Wydawnictwa Ziemia Kłodzka. Samorządowiec (na szczeblu gminnym, powiatowym i wojewódzkim), stoi na czele Stowarzyszenia Solidarność Polsko-Czesko-Słowacka (zob. http://juliangolak.pl/h/zyciorys/, 7.08.2015). 
dzień 2007 r.). W tym kontekście zwraca się raczej uwagę, iż pozwoliło to na obalenie w znacznej mierze wzajemnych stereotypów i postrzegania sąsiadów z obu stron granicy: „po tym jak znieśli granicę to na pewno dużo się zmieniło [...] jedzie się jak do siebie, to znaczy nie ma już tych fizycznych granic to świat postrzega się trochę inaczej” (NR/D/03).

Jak wspomniano od momentu członkostwa w UE możliwość pozyskiwania środków na kooperację na pograniczu jest zauważalnie większa. W odczuciu pytanych znalazło to odzwierciedlenie w intensyfikacji działań, co niekiedy wręcz przybierało formę szukania partnerów po drugiej stronie granicy „na siłę” (NR/L/04). Zauważano, iż celem bliższej kooperacji było zintegrowanie się z czeskim sąsiadem, co z pewnością - wziąwszy pod uwagę częstotliwość spotkań - w jakimś sensie (choć trudnym do określenia) nastąiło.

Z badań dość jednoznacznie wynika, iż można wskazać instytucje, urzędy, które w pewien sposób zdominowały współdziałanie. Należą do nich przede wszystkim urzędy gmin (oraz podległe im jednostki, np. biblioteki i szkoły) oraz ochotnicze straże pożarne. Stosunkowo rzadko partnerami $w$ tego typu inicjatywach są organizacje pozarządowe z prawdziwego zdarzenia (NR/B/06, NR/J/01, NR/J/02, NR/J/04, NR/L/04, $\mathrm{NR} / \mathrm{P} / 02, \mathrm{SZ} / \mathrm{N} / 02, \mathrm{SZ} / \mathrm{SZ} / 04)$. Często wymieniano straż pożarną jako tę instytucję, która skorzystała na tego rodzaju współpracy zarówno jeśli chodzi o poprawę stanu sprzętu, którym dysponuje, jak i częstotliwość spotkań np. przy organizacji Dnia Strażaka i innych wspólnych imprez i zawodów na pograniczu (NR/B/06, NR/J/01, SZ/SZ/15, NR/W/01). Co zadziwiające, rzadko wśród podmiotów utrzymujących kooperację wymieniano szkoły wszystkich typów. Należałoby zatem wyraźnie wskazać, iż możliwości w tym zakresie pozostają ciagle niewykorzystane, nie wspominając już o konieczności poznania języka sąsiada, przynajmniej w stopniu podstawowym, co mogłoby przyczynić się do pogłębienia kontaktów.

Wśród dziedzin współdziałania, które szczególnie rzucają się w oczy na czoło wysuwa się turystyka. Nie może to dziwić, bowiem obszar ziemi kłodzkiej i tereny przygraniczne w Republice Czeskiej bezsprzecznie są obszarami atrakcyjnymi dla turystów. W praktyce turystyka zapewnia dużą liczbę miejsc pracy, w związku z czym jej znaczenie jest tym bardziej istotne. W odniesieniu do współpracy transgranicznej temat ten pojawiał się zarówno jako element tejże, jak i jako aktywność pozwalająca na lepsze wzajemne poznanie obu społeczności. Obecnie nikogo już nie dziwi, iż do Czech Polacy jeżdżą jako turyści, a ziemię kłodzką 
odwiedzają czescy rowerzyści czy turyści pieszy. Nie chodzi w żadnym wypadku o przemieszczanie się mające podtekst handlowy (jak kiedyś), choć i tego typu zjawiska mają jeszcze w ograniczonym stopniu miejsce (NR/W/03, NR/B/10). Polacy odwiedzający turystycznie Czechy oceniają, iż zagospodarowanie pod tym względem znajduje się u południowego sąsiada na wyższym poziomie niż w Polsce (NR/J/03, NR/SO/03, SZ/SZ/03). $\mathrm{W}$, jak się wydaje, jednak nieco przerysowanej opinii dotyczącej porównania rozwoju turystycznego po obu stronach granicy stwierdzono, iż „tam [tzn. w Czechach - przyp. K. K.] stoi ładna budka, ławeczka, u nas nie ma ławeczki, bo ktoś ją ukradł, albo spalił" (NR/SO/03). Łączyło się to również ze stwierdzeniem, że czeskie inwestycje w turystykę są obliczone na dłuższy czas, w przeciwieństwie do polskich, są trwalsze.

Tego rodzaju oceny nawiązują też do ogólnych spostrzeżeń związanych z oceną kontaktów polsko-czeskich na pograniczu. Ich najkrótszym podsumowaniem jest stwierdzenie pojawiające się w wielu wywiadach przeprowadzonych w trakcie badań: „w Czechach jest lepiej”. Dlaczego? Respondenci uzasadniali to kilkoma przyczynami: rzekomo lepiej przeprowadzoną transformacją ustrojowo-gospodarczą w Republice Czeskiej, mniejszym bezrobociem tamże, większą łatwością w prowadzeniu działalności gospodarczej, wypracowaniem tzw. marek (produktów) narodowych $^{10}$ - znanych i kojarzonych w całym świecie z Czechami, lepszym funkcjonowaniem służby zdrowia, wreszcie stosunkowo powszechnym zjawiskiem na ziemi kłodzkiej, jakim są dojazdy Polaków do pracy w Czechach (NR/J/05, NR/J/07, NR/L/04, NR/L/05, NR/P/03, SZ/SZ/03, $\mathrm{SZ} / \mathrm{SZ} / 11, \mathrm{SZ} / \mathrm{t} / 02, \mathrm{SZ} / \mathrm{SZ} / 15, \mathrm{SZ} / \mathrm{SZ} / 16)$. Pytani zdecydowanie podkreślali, iż Czechy powinny stanowić wręcz wzór dla polskich przemian transformacyjnych, lecz niektórzy nie omieszkali zauważyć, że „u nas wszystko zmieniło się przez ten czas [tzw. ostatnie 20-25 lat - przyp. K. K.] dużo bardziej niż u nich, i to na lepsze. Pojechaliśmy z rodziną turystycznie i coś tam nam zabrakło więc trzeba było podjechać do najbliższej miejscowości. I co? Tam wszystko zamknięte, cisza i spokój i nic się nie dzieje. Miałam takie wrażenie, że to się jakoś u nich cofnęło” (SZ/SZ/12). Opinia o rzekomym lepszym rozwoju Czech po upadku systemu komunistycznego najczęściej sprowadza się do ogólnych stwierdzeń, niepopartych konkretnymi przykładami. Trudno za takowe uznać komunikat: ,Jedzenie mają fajne, potrafią się zagospodarować [...]

${ }^{10}$ Najczęściej jako przykład przywoływano markę samochodów Škoda (choć obecnie jest to część koncernu bynajmniej nie czeskiego), piwo Pilzner oraz likier Becherovka. 
Wystarczy na nich popatrzeć to od razu widać weselsze gęby, u nas pan tego nie uświadczysz" (NR/B/08). Oceny te nie są zbieżne z badaniami opinii publicznej prowadzonymi w obu państwach. Według tych badań sytuacja ekonomiczna Polaków nie jest gorsza niż Czechów, wręcz przeciwnie (Opinie, 2015) ${ }^{11}$. Nie sposób zakwestionować wpływu jaki proces integracji europejskiej, zniknięcie granic, wywarły na wzajemne poznanie, doświadczenie dosłownie codziennego spotkania z ludźmi z drugiej strony granicy. Wpływ ten jest bezsprzecznie pozytywny i pozwala na lepsze niż dotąd możliwości współpracy. Otwartym pozostaje pytanie, czy możliwości te są w pełni wykorzystane?

Proces kooperacji na obszarze przygranicznym umożliwił także dostrzeżenie różnic między obiema społecznościami. Osoby zaangażowane w te działania, ale też obserwujące je tylko z zewnątrz, formułowały spostrzeżenia związane z przeszkodami (bądź ich brakiem) jeśli chodzi o współpracę. Stosunkowo często pojawiało się stwierdzenie, że Czesi są niełatwym partnerem $(\mathrm{NR} / \mathrm{B} / 01)$, „nie są bardzo chętni” ( $\mathrm{NR} / \mathrm{J} / 03)$, mają inną mentalność (NR/J/05, NR/SO/04, NR/P/01), są ,specyficznym bardzo narodem, bardzo pragmatycznym” (NR/L/04), a mimo to ,powinni być dla nas wzorem, zwłaszcza ich gospodarność" (NR/P/01). Jeden z rozmówców owe różnice mentalne ujął w następujący sposób: „My mamy inną mentalność [...] Czesi są narodem o charakterze chłopskim, nieufność, podejście bardzo pragmatyczne" (NR/SO/04). Choć niewątpliwie mają miejsce różnice między Polakami a Czechami to należy zaznaczyć, iż opinia o Czechach jest zdecydowanie pozytywna. Tym samym potwierdza to badania ogólnopolskie, według których Czesi należą do narodów najbardziej lubianych przez Polaków (Stosunek, 2015) 12. $^{2}$

Z badań wypływa również wniosek, że zarówno stereotypy, jak i wydarzenia z przeszłości nie mają zasadniczo żadnego wpływu na współpracę transgraniczną. Ziemia kłodzka była po II wojnie światowej miejscem sporu terytorialnego między Pragą a Warszawą. Po zakończeniu wojny strona czechosłowacka wysuwała pretensje do dawnych obszarów leżą-

11 W lutym 2015 r. 46\% Polaków i 41\% Czechów oceniało warunki materialne swojego gospodarstwa domowego jako dobre. Na przełomie 2009 i 2010 r. opinię taką wyraziło 39\% Polaków i 35\% Czechów.

12 Według badań przeprowadzonych w styczniu 2015 r. 50\% pytanych wyraża w stosunku do Czechów sympatię, 30\% obojętność, a 14\% niechęć. Większą sympatią od Czechów cieszyli się jedynie Włosi (51\%). W 1994 r. sympatię wobec Czechów wyrażało 30\%, a najlepszy rezultat zanotowano w 2012 r. (58\% deklarujących sympatię). 
cych w granicach państwa niemieckiego powołując się m.in. na obecność ludności czeskiej w tzw. Czeskim Kątku (kilkanaście miejscowości wokół Kudowy Zdroju). Rozmówcy nie nawiązywali do tych wydarzeń (poza jednym przypadkiem) co wynikało, jak się wydaje, z tego, że problematyka ta nie ma wpływu na obecne wzajemne postrzeganie, a także nie jest powszechnie znana. Wśród ewentualnych wydarzeń historycznych, które mogą mieć znaczenia i rzutować na współczesność - co jednak w mojej opinii nie ma miejsca - wymieniono interwencję w Czechosłowacji w 1968 r. i spór obu państw po I wojnie światowej (NR/J/04, NR/P/02). Trudno byłoby również stwierdzić, iż istniejące przecież ciągle stereotypy i uproszczenia dotyczące wzajemnego postrzegania w jakikolwiek sposób znajdowały przełożenie na obecną sytuację. Zresztą część tychże stereotypów uznawana była przez rozmówców nawet za zaletę danej społeczności: „tam w Czechach nikt do księdza na kolanach nie chodzi, a władze nie pytają episkopatu co mogą zrobić, a co nie" (SZ/SZ/16), „zmieniły się relacje czesko-polskie [...] musieliśmy współpracować z Czechami i na odwrót, to przełamało wiele barier. Czesi zobaczyli, że Polacy to nie tylko kombinatorzy i złodzieje, ale dobrzy organizatorzy i przez to zaczęli na nas inaczej patrzeć" (SZ/SZ/09). Częstotliwość wzajemnych kontaktów wywarła zatem zauważalny wpływ na sposób postrzegania po obu stronach granicy.

\section{Podsumowanie}

Po ponad dwóch dziesięcioleciach współpraca transgraniczna Polski i Czech na pograniczu ziemi kłodzkiej, i nie tylko, stała się wręcz codziennością. Mimo to, jak wynika z przedstawionych wyników badań, nie jest to zagadnienie szeroko znane społeczności lokalnej. Poziom wiedzy na ten temat jest zróżnicowany, bez wątpienia fakt bezpośredniego zetknięcia się z tego typu inicjatywami odgrywa ważną rolę. Władze lokalne powinny zatem szerzej zaangażować się w promocję korzyści wynikających z tej formy współpracy z Czechami.

Zarówno wzajemne stereotypy, ciągle przecież występujące, jak i wydarzenia z przeszłości nie odgrywają żadnej roli w kooperacji wzdłuż granicy. Ta ostatnia stała się zresztą, szczególnie po wejściu obu państw do strefy Schengen, linią kompletnie niedostrzegalną. Respondenci oceniają, iż wspólne projekty na pograniczu nabrały rozmachu od momentu członkostwa Polski i Czech w Unii Europejskiej (łączą to z większymi 
możliwościami finansowania tego typu przedsięwzięć). Bez wątpienia korzyści finansowe płynące $\mathrm{z}$ tego rodzaju kooperacji wzmacniają ją. Równocześnie stosunkowo często podkreślano, że już w latach 90. na ziemi kłodzkiej zainicjowano pewne procesy w tym zakresie, obecnie są one jedynie kontynuowane (m.in. powstanie Euroregionu Glacensis). Faktem jest, iż współpraca transgraniczna przyczyniła się do poprawy postrzegania Czechów, lepszego ich poznania, wychodzącego poza jedynie ogląd zewnętrzny. Codziennością jest wzajemny kontakt, Polacy odwiedzają południowych sąsiadów nie w celach handlowych, nie z powodu różnicy cen, ale najczęściej turystycznie. Podobny przepływ ludzi następuje w drugą stronę.

Wśród dziedzin współpracy dominuja, w ocenie badanych, projekty związane z turystyką. Większość tych inicjatyw jest firmowana przez urzędy gmin i podległe im jednostki, względnie przez ochotnicze straże pożarne. Organizacje pozarządowe odgrywają w tym procesie rolę marginalną. Zauważalna część projektów skupia się także na sferze kulturalnej.

Częstotliwość wzajemnych kontaktów spowodowała, iż pojawiają się oceny południowych sąsiadów, zarówno jako państwa, jak i społeczeństwa. Rzuca się w oczy podkreślanie, wręcz na każdym kroku, iż - kolokwialnie to ujmując - „W Czechach jest lepiej”. Według rozmówców lepiej miała tam zostać przeprowadzona transformacja ustrojowa i gospodarcza, w lepszym stanie jest infrastruktura drogowa, turystyczna, prawie nie jest dostrzegalne bezrobocie, zdecydowanie mniej państwowych zakładów pracy zostało zlikwidowanych, generalnie ,życie w Czechach jest spokojniejsze". Jest to jednak ocena powierzchowna, bowiem rozmówcy najczęściej nie potrafią konkretnie wskazać przyczyn takiej oceny. Nierzadko udowodnienie tej tezy sprowadza się do faktu, iż to Polacy z ziemi kłodzkiej jeżdżą do pracy w Czechach, a nie na odwrót. Rozmówcy zauważają także, iż Czesi różnią się od Polaków mentalnością, mniejszą gościnnością, mniej garną się do współpracy transgranicznej. Nie zmienia to faktu, iż są postrzegani bardzo pozytywnie, a niektórzy widzą w nich wręcz wzór gospodarności.

Współpraca transgraniczna z punktu widzenia mieszkańców ziemi kłodzkiej jest zatem zjawiskiem ocenianym pozytywnie. Dostrzega się jej znaczenia dla zbliżenia społeczności żyjących po obu stronach granicy, która obecnie - co można szczególnie zaakcentować - faktycznie łączy, a nie dzieli, jak jeszcze pod koniec lat 80 . XX wieku.

Przytaczając opinię mieszkańców polskiego pogranicza warto wziąć pod uwagę punkt spojrzenia społeczeństwa czeskiego. Badania prze- 
prowadzone w 2008 r. przez Centrum pro výzkum veřejného mínění (CVVM) wykazały istniejącą dychotomię między obszarami pogranicznymi a resztą państwa (Novotný, 2009, s. 27-32). Ankietowani określenie ,pogranicze" wiążą aż w ponad 92\% (suma odpowiedzi na tak lub raczej tak) z możliwością współpracy z sąsiednimi państwami, choć w tym kontekście najrzadziej jest wymieniana kooperacja na granicy z Polską ${ }^{13}$. Zauważa się wpływ, jaki na tego rodzaju kooperację ma wstąpienie do UE, co ma się wyrażać przede wszystkim możliwością korzystania z funduszy strukturalnych Unii (opinia ponad 84\% pytanych) oraz bliską kooperacją z sąsiednimi gminami (prawie 77\% wskazań). Za czynnik niemający większego wpływu na współpracę także i w Czechach uznano ewentualny brak zaufania będący pochodną najnowszych dziejów.

Uzasadnione jest zatem stwierdzenie, iż spojrzenie na konieczność współpracy transgranicznej, możliwości jakie stwarza ona w obliczu członkostwa w UE zarówno po stronie polskiej, jak i czeskiej jest zbliżona.

\section{Bibliografia}

15 lat Euroregionu, http://www.euro-glacensis.cz/files/vyrocni_zpravy/euroregion glacensis_15_let_zkusenosti_pl.pdf, 28.06.2015.

Dostál V., Kałan D. (2014), Granica w czasach Schengen: szanse i wyzwania polskoczeskiej wspótpracy transgranicznej, „PISM Strategic File”, nr 21 (57).

Euroregiony na granicach Polski 2007 (2007), red. M. Czekaj, Wrocław.

Goliński M. (1994), Pstrażna. Z przeszłości „zakatka czeskiego” Ziemi Kłodzkiej, „Zeszyty Muzeum Ziemi Kłodzkiej”, z. 5.

Novotný L. (2009), Názory a postoje české populace na přeshranični spolupráci. „Naše společnost”, $\mathrm{nr} 1$.

Opinie i prognozy sytuacji gospodarczej oraz warunków materialnych gospodarstw domowych w Polsce, Czechach, na Stowacji i Wegrzech (2015), „Komunikat z badań CBOS", nr 34/2015, Warszawa.

Powierzchnia i ludność w przekroju terytorialnym w 2014 r. (2014), GUS, Warszawa.

Program operacyjny wspótpracy transgranicznej Polska-Czechy 2007-2013 (2008), MEMO/08/388, 11 czerwca 2008, Bruksela, europa.eu/rapid/press-release MEMO-08-388_pl.pdf, 3.08.2015.

${ }^{13}$ W tym kontekście po stronie czeskiej za powód stosunkowo słabej współpracy często wymieniane są: brak połączeń transgranicznych o charakterze ponadregionalnym, oddalenie od dużych centrów gospodarczych i ubytek ludności (migracje z pogranicza). 
Siatkowski J. (1990), Obecna sytuacja językowa w okolicy Kudowy, w: Tgoli chole Mêstró. Gedenkschrift für Reinhold Olesch, red. A. Lachmann, A. Lauhus, T. Lewandowski, B. Zelinsky, Köln-Wien.

Skorupska A. (2014), Wspótpraca samorzqdowa na pograniczu polsko-czeskim, „PISM Policy Papers”, nr 17 (100).

Skorupska A. (2015), Dyplomacja samorzqdowa. Efektywność i perspektywy rozwoju, Warszawa.

Stosunek do innych narodów (2015), „Komunikat z badań CBOS”, nr 14.

Strategia Rozwoju Powiatu Kłodzkiego na lata 2008-2015 (2008), Kłodzko, http://www.powiat.klodzko.pl/plik/id,800.pdf?otworz=1\%20TARGET=, 2.08.2015.

Szadkowska E. (2010), Pojęcie współpracy transgranicznej, w: Wspótpraca transgraniczna. Aspekty prawno-ekonomiczne, red. M. Perkowski, Białystok.

Trzebiński W. (1952), Niemieckie podziały administracyjne ziem polskich $w$ okresie 1815-1945. Zarys historyczny, Warszawa.

Żochowska M. (2011), Aktywność członków Euroregionu Glacensis w pozyskiwaniu funduszy unijnych, ,Słupskie Prace Geograficzne”, nr 8.

\section{Cross-border cooperation at the local level. The inhabitants' of the district of Klodzko opinions on the cooperation with the Czech partner}

\section{Summary}

The study, carried out with the use of in-depth interviews, comprised two communities of the Kłodzko district: Nowa Ruda (rural community) and Szczytna. They referred to the perceptions of cross-border cooperation. The cooperation was initiated in the 90s of the twentieth century. Since the accession of Poland and the Czech Republic to the EU it has been intensified.

Cross-border cooperation is not the subject well-known to the residents of these communities. They evaluate these actions positively as contributing to a better mutual understanding and frequent direct contacts between Poles and Czechs. This cooperation has a significant impact on the positive perception of the southern neighbours. Many speakers even considered the Czech Republic as a model of economy. This assessment was, however, superficial and was not supported by any specific evidence.

Cross-border cooperation in the district of Kłodzko concerns mainly such spheres as tourism and culture, and it is mostly coordinated by the municipal offices and their subordinate units. The involvement of NGOs in these processes is, in the opinion of respondents, hardly noticeable. To strengthen the cooperation it would be necessary to improve the communication network, in particular railway connections.

Key words: Kłodzko County, crossborder cooperation, Poland, Czech Republic 